\title{
Dynamic Multiline Population Approach to Resistance Gene Management
}

\author{
J. P. Wilson, R. N. Gates, and M. S. Panwar
}

First and second authors: USDA-ARS Crop Genetics and Breeding Research Unit, University of Georgia Coastal Plain Experiment Station, Tifton 31793; and third author: Chaudhary Charan Singh Haryana Agricultural University, Hisar 125 004, Haryana, India. Accepted for publication 5 December 2000.

\section{ABSTRACT}

Wilson, J. P., Gates, R. N., and Panwar, M. S. 2001. Dynamic multiline population approach to resistance gene management. Phytopathology 91:255-260.

The dynamic multiline population breeding strategy integrates principles from the gene stacking and multiline approaches and allows application of the multiline strategy to cross-pollinated hybrid crops. Experiments were conducted to evaluate the effectiveness of the breeding approach. Backcross derivatives of pearl millet Tift 23DB were developed with rust resistance from 18 Burkina Faso landraces, 3 Pennisetum glaucum subsp. monodii accessions, and 2 elite inbreds ( 1 from India and 1 from the United States). Four cycles of open pollination were made, the last two in the field in rust epidemics. Cytoplasmic male-sterile (CMS) counterparts of the populations in the $\mathrm{A}_{4}$ cytoplasm were included and advanced simultaneously with the B population. Hybrids with Tift 383 were produced on CMS cycles 1 (C1) through $\mathrm{C} 4$. Frequency of hybrid seedlings with resistance increased with each cycle, and frequencies averaged 18 to $38 \%$ in $\mathrm{C} 1$ to $\mathrm{C} 4$ hybrids, respectively, when inoculated with five single-uredinium isolates of Puccinia substriata var. indica. The hybrid populations and Tifleaf (TL)1 and TL2 were evaluated in three yield trials in 1998 to 1999. Disease-free forage dry matter yields did not differ among hybrids. Across trials, area under the disease progress curve (AUDPC) of TL1 and TL2 averaged 1,307, C1 and C2 averaged 914, and C3 and C4 averaged 604. Final severities of TL1 and TL2 averaged $67 \%, \mathrm{C} 1$ and $\mathrm{C} 2$ averaged $47 \%$, and C3 and C4 averaged $30 \%$. When analyzed by regression analysis, AUDPC was reduced $12.2 \%$, final rust severity was reduced $13.3 \%$, and digestible biomass was increased $4.1 \%$ per cycle.
Developing durable disease resistance requires strategies that limit the ability of pathogen populations to adapt to host resistance. Coevolution between plants and pests is hypothesized to follow various courses: (i) an escalating "arms race" in which plants and pathogens acquire and accumulate genes conferring defense and virulence mechanisms, (ii) cyclical selection of extremes in resistance and virulence which decline because of reproductive costs associated with those traits when unnecessary, or (iii) a stasis that entails little evolutionary change because of specific constraints that limit opportunities for evolution (5). The first two scenarios are frequently observed and researched in agricultural systems. The last scenario is generally considered to be an attribute of natural populations of nondomesticated species. Strategies for thwarting the adaptation of pathogens to crops are usually based upon these hypotheses.

The ephemeral effectiveness of resistance to some diseases with great epidemic potential has resulted in considerable research into the nature of durable disease resistance. Efforts have been devoted to understanding the relative merits of variation in expression of different types of resistance genes (i.e., hypersensitive, partial, and growth- or temperature-dependent resistances), and the implications of gene deployment strategies (such as gene stacking and multiline approaches). In spite of the efforts devoted to understand durable disease resistance, very few examples have been confirmed, and are necessarily identified as durable only in retrospect.

Following the demise of the effectiveness of single gene resistance because of race changes in pathogen populations, resistance breeding strategies usually take one of two courses; the gene stacking or the multiline approach. The gene stacking approach

Corresponding author: J. P. Wilson; E-mail address: jwilson@tifton.cpes.peachnet.edu

Publication no. P-2001-0116-01R

This article is in the public domain and not copyrightable. It may be freely reprinted with customary crediting of the source. The American Phytopathological Society, 2001. incorporates different resistance genes into a plant selection that is then grown as a homogeneous population, whereas the multiline strategy disperses resistance genes among different plants that are grown as a heterogeneous population. Theoretical models have been used to estimate the longevity of crop protection afforded by three highly effective resistance genes used under different strategies (16). In the absence of stabilizing selection in the pathogen, the models indicated few differences if the genes were used sequentially (13 to 14 years), stacked into a single multigenic variety (13 to 14 years), or used in a multiline (12 to 13 years). In these evaluations, the composition of the multigenic and multiline host populations were static from year to year. Alternative strategies for resistance gene management would be useful.

Disease epidemics are primarily an artifact of simplified ecosystems. In general, epidemics tend to be less significant in natural plant communities, landrace cultivars, and cross-pollinated forage crops. There is a higher potential for epidemics in hybrid crops, and the potential is greatest in inbred cultivars. Pearl millet (Pennisetum glaucum (L.) R. Br.) is a unique model system in which to examine durable resistance concepts, because it is or has been grown as landrace, open-pollinated forage, and hybrid cultivars. The move toward higher-yielding hybrid cultivars has resulted in rapid selection for virulent pathogen biotypes causing downy mildew (Sclerospora graminicola (Sacc.) J. Schröt.) in India (15) and rust (Puccinia substriata Ellis \& Barth. var. indica Ramachar \& Cumm.) in the United States (18). Resistance in production systems must be maintained by finding new resistance genes and developing and deploying appropriate cultivars. Stable production depends on the existence of new resistance genes, which are summarily rendered ineffective by the pathogen. Alternative strategies of using genes must be examined to slow or halt the erosion of available resistance genes, which are currently being used as "nonrenewable" or "disposable" resources.

The dynamic multiline population approach has been proposed for use in cross-pollinated hybrid crops $(13,22)$. This approach integrates the best attributes of both the gene stacking and multi- 
line strategies, in that a high frequency of the heterogeneous host population possesses multigenic resistance. The method is likely to provide greater longevity to the effectiveness of resistance genes because the genetic composition of the host does not remain static from year to year. The general procedure of producing a dynamic multiline population is summarized below.

After backcrossing different resistance genes into an elite genetic background to develop near-isogenic derivatives, random mating is allowed to occur in the presence of disease pressure for several generations. Simultaneous advancement of a cytoplasmic male sterile (CMS) counterpart with the fertile B population can be achieved by including rows of a CMS derivative of the elite genetic background in isolation crossing blocks. Dynamic multiline hybrids can be made using the CMS derivative of the dynamic multiline population as the seed production parent in a cross with an appropriate pollinator.

Development of dynamic multiline hybrids is most suitable for systems that meet certain criteria, including (i) diverse sources of resistance to a genetically diverse pest population, (ii) host biology permitting open-pollinated population development and hybrid production, including a cytoplasmic-genic male sterility and restoration system, and (iii) elite inbreds suitable for producing high-yielding hybrids.

In theory, the dynamic multiline population is a potentially powerful approach to managing resistance genes, particularly as the number of resistance genes increases. The simplest model of a dynamic multiline population is illustrated by a population developed by $N$ isogenic component inbreds, each with a single gene and constituting $1 / N$ of the population. All resistance genes are assumed to be dominant, loci are independent, and there is no selective or reproductive advantage associated with resistance genes. In this extremely simplified model, the number of resistance gene associations in a random-mating population in HardyWeinberg equilibrium is an exponential function of the number of resistance loci in the population. With dominant, unlinked genes for resistance, the number of phenotypes is $P=2^{x}$ and the number of genotypes is $G=3^{x}$, where $x=$ the number of resistance genes in the population. The number of phenotypes in a standard multiline is equal to the number of resistance genes $(P=x)$ if each component of the multiline has a single resistance gene. The Shannon index of diversity can be used to compare the number of distinct phenotypes or genotypes and the evenness of the distribu-

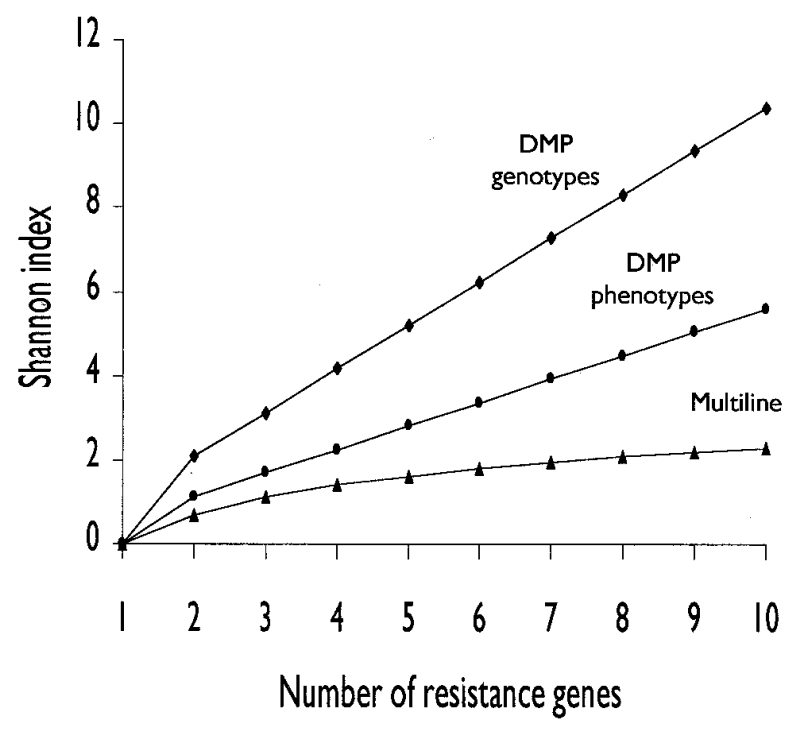

Fig. 1. Shannon index of diversity based upon the number of resistance genes in a standard multiline and for phenotypic and genotypic diversity expected in a dynamic multiline population in Hardy-Weinberg equilibrium with unlinked, dominant genes for resistance. tion of their frequencies (11). The index $\left(I=-\Sigma p_{i} \ln \left[p_{i}\right]\right.$, where $p_{i}=$ frequency of $i$ th individual] is a linear function of the number of resistance genes for both phenotypes and genotypes if resistance genes are assumed to be dominant and independent (Fig. 1). The Shannon index of a standard multiline is a curvilinear function of the number of resistance genes, and approaches an asymptote. The indices in Figure 1 represent upper limits expected for simplified model populations. Variations from model assumptions would reduce index values.

A dynamic multiline population hybrid with resistance to rust, caused by $P$. substriata var. indica, has been developed in forage pearl millet. The pathogen population is highly diverse for virulence, and the available resistance genes have only a limited effectiveness against the spectrum of races (12). The objective of these experiments was to test the hypotheses that disease-resistant hybrids can be developed, that resistance would become more effective in advanced cycles, and that forage yield and quality is unaffected by the application of the dynamic multiline population strategy.

\section{MATERIALS AND METHODS}

Population development. Twenty-three different sources of rust resistance (Table 1) were backcrossed into a Tift 23DB background. Race-specific resistance reactions indicated that most of the resistances were different (12). Dwarf, rust-resistant back $\operatorname{cross}_{4} \mathrm{~F}_{3}$ progeny with desirable agronomic traits and homozygous for resistance were selected from field trials in 1994. Seed from these selections were used to plant five pots of each entry in the greenhouse. Stands were thinned to three plants per pot. The 5 pots of each resistance source and 22 pots of Tift $23 \mathrm{DA}_{4}$ were randomized within a crossing tent in the greenhouse and allowed to cross-pollinate in isolation. Cross-pollination was facilitated by providing air circulation with a fan and manually shaking the plants daily during pollination.

Equal quantities of seed from each open-pollinated resistance source were bulked to form the fertile dynamic multiline population DMP-B cycle 1. This seed was used to plant 300 pots, thinned to three to five plants each. The seed formed on Tift $23 \mathrm{DA}_{4}$ were bulked to create the male-sterile DMP-A $\mathrm{A}_{4}$ cycle 1 , which was planted in 60 pots and interspersed among the fertile DMP-B population. Cross-pollination was conducted as described

TABLE 1. Sources of resistance to pearl millet rust, Puccinia substriata var. indica, backcrossed into a Tift 23DB genetic background and included in the dynamic multiline population

\begin{tabular}{ll}
\hline Source of resistance & Accession \\
\hline Burkina Faso landraces & BF 17 \\
& BF 19 \\
BF 34 & BF 41 \\
BF 49 \\
BF 53 \\
BF 122 \\
BF 137 \\
BF 156 \\
BF 178 \\
BF 191 \\
BF 201 \\
BF 202 \\
BF 221 \\
BF 296 \\
BF 299 \\
Improved inbreds & BF 334 \\
& BF 337 \\
& PS 727 \\
& PS 748 \\
& PS 756 \\
& Tift 8677 \\
& ICMP 83506 \\
\hline
\end{tabular}


above. All seed produced on the DMP-B plants were bulked to form the fertile DMP-B cycle 2. Seed produced on the DMP-A plants were bulked to form the sterile DMP- $\mathrm{A}_{4}$ cycle 2 population.

Seed of cycle 2 of DMP-B and DMP-A 4 were planted in an isolated crossing block in the field in 1995. Four two-row plots (42 $\mathrm{m}$ long) of the DMP-A $\mathrm{A}_{4}$ population were separated and surrounded by four-row plots of the DMP-B population. After open pollination, harvested seed were bulked within the fertile and sterile rows to form DMP-B and DMP-A $\mathrm{A}_{4}$ cycle 3. Cycle 3 seed was used to plant a crossing block in 1996 consisting of three tworow plots $\left(60 \mathrm{~m}\right.$ long) of the DMP- $\mathrm{A}_{4}$ population separated and surrounded by four-row plots of the DMP-B population. After open pollination, harvested seed were bulked within the fertile and sterile rows to form DMP-B and DMP-A $\mathrm{A}_{4}$ cycle 4 . Plantings were made late in 1995 and 1996 to allow natural rust infection to exert selection pressure on the populations.

Hybrid populations for yield tests were developed in 1997 and 1998 by planting five replications of 6-m-long, two-row plots of sterile DMP-A $A_{4}$ seed from cycles 1 to 4 in the field. Each replication and the entire test was surrounded by the moderately rustsusceptible pollinator Tift 383 . Although Tift 383 has a very low level of race nonspecific, partial resistance (19), its resistance is ineffective when heterozygous (J. P. Wilson, unpublished data). Tift 383 was used because it is the pollinator of the commercial hybrids Tifleaf 1 and Tifleaf 2, and use of a resistant pollinator would confound comparisons of the dynamic multiline populations. Seed produced on sterile DMP-A 4 plots were bulked within cycle.

Greenhouse evaluations. The sterile $\mathrm{A}_{4}$, fertile $\mathrm{B}$, and hybrid cycles were inoculated as seedlings at the three- to four-leaf stage with bulk rust inoculum collected from susceptible plants in the field in 1995. An average of 16 plants of each population were inoculated in each of five replications (pots) and arranged as a randomized complete block design. The experiment was repeated three times. Proportions of plants with resistance were recorded in each replication. Because plants in the host populations were heterogeneous for resistance, and pathogen inoculum was likely to be heterogeneous for virulence, it was not unusual to observe a mixture of resistant and susceptible infection sites on a plant. Resistant infection types were considered to reveal the presence of resistance genes in spite of a mixed resistance phenotype. Data were analyzed within populations. Sums of squares were partitioned into experiment, replication, and cycle. Mean frequencies of resistance in populations were compared for differences by Fisher's least significant difference (LSD).

The DMP hybrids were also evaluated with single-uredinium isolates. In each of two experiments, the hybrids were planted in six replications (pots). An average of 15 plants per replication were inoculated with urediniospores of isolates PS93-1, PS93-2, PS93-4, PS93-7, and PS93-9. These races were selected based upon the diversity of reaction to the sources of resistance (12). Numbers of resistant and susceptible plants were counted between 10 to 14 days after inoculation. Sums of squares were partitioned into experiment, replication within experiment, year of hybrid seed production, cycle, and production year $\times$ cycle. Mean frequencies of resistance in populations were compared for differences by Fisher's LSD.

Field evaluations. Experiments were planted in 1998 and 1999 to evaluate disease resistance and digestible biomass production of hybrids. In 1998, hybrids Tifleaf 1 (Tift 23DA $\times$ Tift 383), Tifleaf 2 (Tift 85DA $\times$ Tift 383), and the experimental hybrids DMP-A 4 cycle " $n$ " $\times$ Tift 383 (where $n=1$ to 4) produced in 1997 were planted in two yield trials on 19 June 1998 and 11 August 1998. Plots were $6 \mathrm{~m}$ long, with 2-m spacing between rows, arranged in a randomized complete block design with six replications. Plots were harvested with a forage chopper. The first harvest of the first planting was free of rust and taken on 12 August 1998. The regrowth and the second trial were naturally infected by rust. Severities were recorded at weekly intervals from 5 to 28 October 1998. Rust-infected forage from both experiments was harvested 30 October 1998. Plot green weights were measured. Samples $(\approx 400 \mathrm{~g})$ of forage were weighed green and after drying at $60^{\circ} \mathrm{C}$ for $48 \mathrm{~h}$ to determine dry matter proportion (DM). Dry matter yield (DMY) was calculated as the product of green yield and DM. In vitro dry matter digestibility (IVDMD) of samples was estimated using a filter bag system following the procedures outlined by Vogel et al. (17). Three subsamples were analyzed per plot. Digestible dry matter yield (DDMY) was calculated as the product of DMY and IVDMD.

In 1999, one experiment was planted on 8 June 1999. Hybrids were identical to those planted in 1998, but the test also included hybrids produced in 1998 in addition to those planted in 1997. Experimental design and plot dimensions were similar to the yield test in 1998. The first harvest taken on 13 August 1999 was rust free. Rust severities were determined at weekly intervals from 16 September to 8 October 1999. The second harvest was taken on 12 October 1999. DDMY of plots was determined as described above. Data for rust-free and rusted forage were analyzed separately. Sums of squares within the experiments were partitioned into replication and hybrid sources of variation. Analyses indicated no effect of year of hybrid production in the 1999 trial, so year of production was treated as a subsample during analyses. Data from an overall analysis of variance was partitioned into trial, replication within trial, hybrid, and subsample within replication sources of variation.

\section{RESULTS}

Greenhouse evaluations. Host populations were heterogeneous for resistance genes. Thus, when inoculated with a heterogeneous bulk rust inoculum, a mixture of resistant and susceptible infection types were frequently observed on individual plants. The presence of resistant infection sites indicated that a plant possessed resistance to at least some proportion of the pathogen inoculum. When inoculated with a bulk inoculum, the frequency of resistant plants in the fertile DMP-B and sterile DMP-A 4 populations did not change $\left(P<0.05, \operatorname{LSD}_{P}=0.05=11.2\right.$ and 11.4 , respectively) (Fig. 2). Frequency of rust resistance in seedlings increased in advanced cycles of the hybrid populations DMP-A cycles $\times$ Tift $383\left(\operatorname{LSD}_{P}=0.05=12.6\right)$. Cycle 3 and cycle 4 hybrids did not differ from each other, but were greater than means for

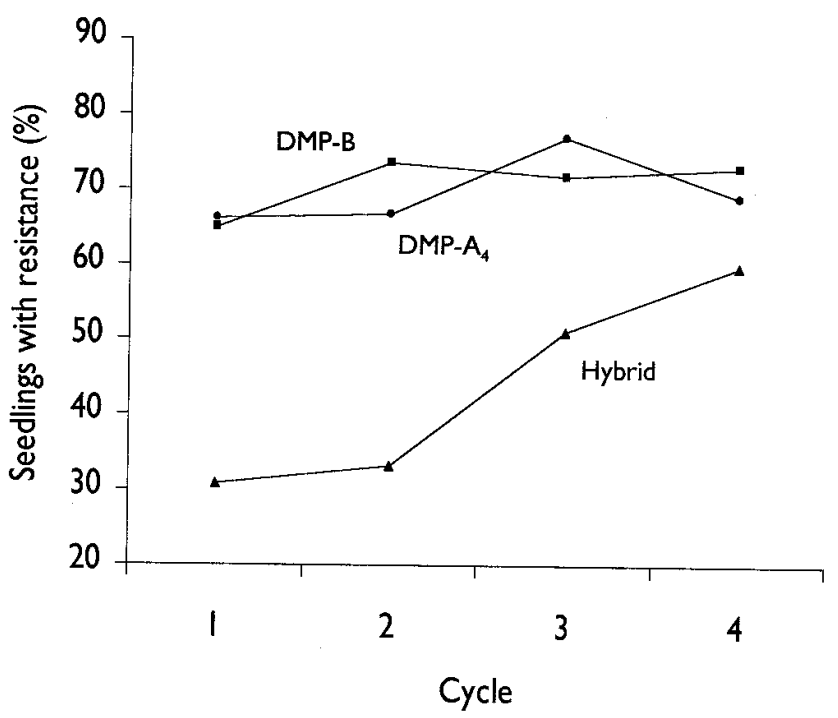

Fig. 2. Frequencies of rust resistance in pearl millet fertile (DMP-B) and sterile $\left(\mathrm{DMP}-\mathrm{A}_{4}\right)$ dynamic multiline populations, and for the hybrids of DMP-A $_{4} \times$ Tift 383 , when inoculated with a bulk urediniospore inoculum. 
cycle 1 and cycle 2 hybrids. This increase is probably a reflection of the increased frequency of multiple gene resistance (gene stacking) in the DMP, because the potential heterogeneity for resistance is reduced in a hybrid compared to the parental heterozygous plant.

In the analyses of variance in inoculations of hybrid populations with single-uredinium isolates, experiment effect was significant $(P<0.05)$ only for inoculations with PS93-1 and 93-2. Year of hybrid production effect was significant $(P<0.05)$ for all isolates. The reason for this difference is not clear. When analyzed over all isolates and cycles, $33.8 \%$ of plants produced in 1998 expressed seedling resistance, whereas $24.3 \%$ of plants produced in 1997 expressed seedling resistance. Cycle was a significant $(P<0.05)$ source of variation for all isolates. Average frequency of resistant plants in the cycle 1 through cycle 4 hybrids were 17.8, 28.7, 33.1, and $37.8 \%$, respectively $\left(\operatorname{LSD}_{P=0.05}=3.9\right)$. When hybrid seedlings were inoculated with single-uredinium isolates of $P$. substriata var. indica, frequency of resistant plants increased from cycle 1 to cycle 2 for all isolates (Fig. 3). There was a trend toward stable or increasing rust resistance in latter cycles. Frequency of resistant plants remained stable to isolates PS93-4 and PS93-7, whereas frequency increased for isolates PS93-1, PS93-2, and PS93-9.

Field evaluations. In the harvest of rust-free forage (1998, trial 1 , harvest 1 and 1999 harvest 1$)$, no differences $(P>0.05)$ in DMY, digestibility, or DDMY existed among hybrids (Table 2). Minor differences in height existed, with cycle 3 and cycle 4 hybrids tending to be slightly taller.

Data trends were similar for diseased plots from both planting dates in 1998; however, because planting date was a significant source of variation $(P<0.05)$ for yield and disease variables, these data were analyzed separately. Results were similar $(P>$ 0.05) for diseased plots from both seed lots for the test evaluated in 1999. Year of seed production was not a significant source of variation $(P>0.05)$ for yield and disease; therefore, hybrids from each year of production were considered to be subsamples within treatments for subsequent analyses.

Hybrids did not differ for DMY in the 1998 trials, but did in 1999 (Table 2). Digestibility, DDMY, and height of the experimental hybrids were usually greater than those of Tifleaf 1 and Tifleaf 2, and increased with advancing cycle (Table 2). Linear regression of average digestible DMY against cycle indicated a $4.1 \%$ increase in digestible biomass yield per cycle. Rust severity and area under the disease progress curve (AUDPC) of experimental hybrids tended to be less than those of Tifleaf 1 and Tifleaf

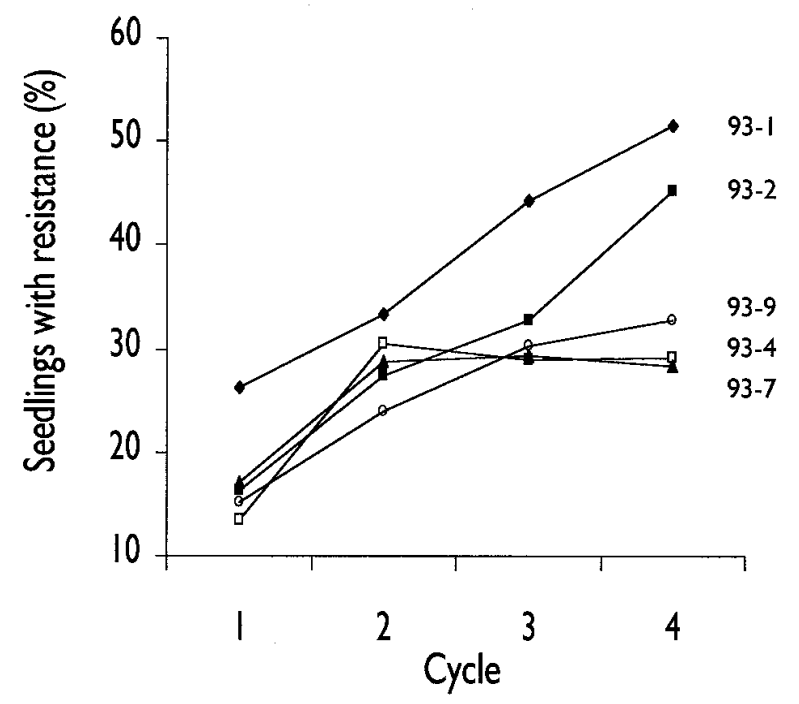

Fig. 3. Frequencies of resistance in dynamic multiline population pearl millet hybrids (DMP- $\mathrm{A}_{4} \times$ Tift 383 ) when inoculated with single-uredinium isolates of Puccinia substriata var. indica.
2 , and were reduced with advancing cycles. Linear regression analyses indicated a $13.3 \%$ decrease in rust severity and a $12.2 \%$ decrease in AUDPC with each cycle.

\section{DISCUSSION}

Our present experiments demonstrate the feasibility of developing hybrids from dynamic multiline populations. An increase in resistance in advancing cycles of the dynamic multiline population was observed in field and greenhouse evaluations, and the resistance of latter cycle hybrids resulted in increased digestible biomass. Based upon known response relationships between rust infection and DDMY $(20,21)$, the digestible biomass yield could be improved beyond that obtained by the cycle 4 dynamic multiline hybrid. At the level of rust severity observed on the cycle 3 and cycle 4 hybrids, significant improvements in digestible biomass yield result from small improvements in rust resistance. Improved resistance of hybrids may be obtained after additional cycles of selection pressure from disease on the resistant parental population or, alternatively, by producing hybrids with a resistant pollinator.

Several theoretical principles and attributes of the dynamic multiline population can be summarized. The dynamic multiline population allows application of the multiline strategy to crosspollinated hybrid crops, while integrating the most favorable attributes of the gene stacking and multiline approaches to resistance breeding. In its simplest form, genotypic and phenotypic diversities within a dynamic multiline population are exponential functions of the number of resistance genes. Selection pressure from disease will tend to select for the most effective genes and gene combinations corresponding to the most prevalent races of the pathogen, reducing the effective genetic diversity. However, pearl millet plants are rarely killed by rust before pollination (J. P. Wilson, unpublished data); therefore, it is unlikely that less effective or recessive resistance genes are completely lost from the population.

Agronomic performance of a dynamic multiline hybrid is expected to be relatively stable across environments. In the absence of yield-limiting diseases, pearl millet hybrids produced by crossing heterogeneous landraces onto cytoplasmic male-sterile inbreds often expressed greater or more stable biomass and grain yield across environments than did their pollinators $(1,7,25)$. The genetic diversity within a dynamic multiline population is likely to be less than that of landraces; however, the current protocol for incorporating resistance into an elite genetic background results in greater phenotypic and genotypic diversity than that of an inbred parental line.

In the presence of diseases, prolonged coevolution of host and pathogen results in selection of host populations with greater resistance. Populations of pearl millets with rust resistance express improved levels of resistance after random mating $(13,14)$. Natural selection in barley composite cross populations grown for many generations favors individual plants which can interact in mixtures to reduce scald severities more effectively than their original parents in mixtures (9). Frequencies of barley plants with resistance to complex races of Blumeria graminis also increase in advanced generations (4).

Disease resistance of the host population must be evaluated from both short-term (within a season) and long-term (over years) perspectives. Within a season, the effectiveness of disease control is expressed as the rate of epidemic development. Effectiveness of resistance resulting from mixtures has been attributed to reduced density of susceptible plants, barrier effects on the spread of inoculum, and induced resistance (2). The role of induced resistance in unknown, but density and barrier principles are likely to play a key role in a dynamic multiline population.

The density of susceptible plants is reduced in a dynamic multiline population after intermating. A high level of genetic hetero- 
geneity results from random mating in the population and, in theory, the genotypic and phenotypic diversity can be expressed as exponential functions of the number of resistance genes. This diversity of resistance genes and gene combinations within the host population should result in greater mixture effectiveness. The number and spatial arrangement of mixture components affects the homogeneous genotype area and mixture efficacy for controlling race-specific pathogens (24). Increasing the number of genotypes within a host population reduces the density of susceptible plants and decreases the size of the homogeneous genotype unit area (10), thus providing more effective disease control.

In addition to reduced density of susceptible components, barrier effects are important in the midstages of epidemic development in mixtures (2). Stacked resistance genes will result in a high frequency of plants with complex and, theoretically, more effective resistance. For example, if eight unlinked resistance loci are included in a random mating synthetic population and the resistance allele frequency at each locus is $0.125,97.3 \%$ of the population will have at least one resistance allele at four or more loci (23) if evaluated under the simplest model assumptions defined earlier. Epidemic development in a dynamic multiline hybrid in a production setting will likely be reduced from what was observed in the present studies. Barrier effects were likely to be minimal in the single-row plots that were used.

Long-term effectiveness of host resistance will depend on the rate of pathogen coevolution with a dynamic multiline population, which is subject to speculation. In theoretical models of a complex mixture of genotypes with overlapping gene sets, the number of component lines in the mixture and their resistance genes are the primary determinants of the pathogen population reaching genetic equilibrium on the host (8). Experimental evidence concerning the actual development and establishment of complex

TABLE 2. Forage yield and disease resistance of dynamic multiline population hybrids evaluated in rust epidemics ${ }^{\mathrm{y}}$

\begin{tabular}{|c|c|c|c|c|c|c|c|}
\hline \multirow[b]{2}{*}{ Hybrid, evaluation $^{\mathrm{z}}$} & \multicolumn{3}{|c|}{ Rust-free forage } & \multicolumn{4}{|c|}{ Rust-infected forage } \\
\hline & $1998 \mathrm{~T} 1 \mathrm{H} 1$ & $1999 \mathrm{H} 1$ & Pooled & $1998 \mathrm{~T} 1 \mathrm{H} 2$ & 1998 T2 H1 & 1999 H2 & Pooled \\
\hline \multicolumn{8}{|l|}{ DMY (kg ha-1) } \\
\hline Tifleaf 1 & 9,783 & 7,925 & 8,544 & 7,777 & 7,662 & $5,813 \mathrm{c}$ & $6,766 \mathrm{~b}$ \\
\hline Tifleaf 2 & 9,816 & 8,616 & 9,016 & 9,228 & 9,059 & $5,703 \mathrm{c}$ & $7,424 \mathrm{ab}$ \\
\hline Cycle $1 \times$ Tift 383 & 11,135 & 8,865 & 9,621 & 7,574 & 9,186 & $6,122 \mathrm{bc}$ & $7,251 \mathrm{ab}$ \\
\hline Cycle $2 \times$ Tift 383 & 9,661 & 9,089 & 9,280 & 8,524 & 8,580 & 6,687 abc & $7,620 \mathrm{ab}$ \\
\hline Cycle $3 \times$ Tift 383 & 11,847 & 9,490 & 10,276 & 7,941 & 9,921 & $6,863 \mathrm{ab}$ & 7,897 a \\
\hline Cycle $4 \times$ Tift 383 & 12,358 & 8,881 & 9,993 & 8,051 & 9,339 & $7,232 \mathrm{a}$ & $7,963 \mathrm{a}$ \\
\hline $\operatorname{LSD}(P=0.05)$ & 4,655 & 1,775 & 1,934 & 2,310 & 2,377 & 986 & 966 \\
\hline \multicolumn{8}{|l|}{ IVDMD (\%) } \\
\hline Tifleaf 1 & $49.9 \mathrm{ab}$ & 66.1 & 59.4 & $47.1 \mathrm{c}$ & $45.7 \mathrm{c}$ & $50.3 \mathrm{c}$ & $47.7 \mathrm{~b}$ \\
\hline Tifleaf 2 & $49.4 \mathrm{~b}$ & 65.7 & 59.1 & $44.4 \mathrm{~d}$ & $44.6 \mathrm{~d}$ & $50.5 \mathrm{c}$ & $46.5 \mathrm{c}$ \\
\hline Cycle $1 \times$ Tift 383 & $51.1 \mathrm{a}$ & 66.2 & 60.0 & $48.6 \mathrm{~b}$ & $48.8 \mathrm{a}$ & $52.4 \mathrm{~b}$ & $49.9 \mathrm{a}$ \\
\hline Cycle $2 \times$ Tift 383 & $50.1 \mathrm{ab}$ & 65.8 & 59.5 & $50.1 \mathrm{a}$ & $46.4 \mathrm{c}$ & $53.3 \mathrm{ab}$ & $49.9 \mathrm{a}$ \\
\hline Cycle $3 \times$ Tift 383 & $46.6 \mathrm{c}$ & 64.7 & 57.1 & $51.3 \mathrm{a}$ & $47.4 \mathrm{~b}$ & $53.6 \mathrm{a}$ & $50.8 \mathrm{a}$ \\
\hline Cycle $4 \times$ Tift 383 & $48.8 \mathrm{~b}$ & 65.2 & 58.2 & $51.1 \mathrm{a}$ & $47.7 \mathrm{~b}$ & $53.0 \mathrm{ab}$ & $50.5 \mathrm{a}$ \\
\hline $\operatorname{LSD}(P=0.05)$ & 2.0 & 2.0 & 3.1 & 1.4 & 0.8 & 1.1 & 1.1 \\
\hline \multicolumn{8}{|l|}{ DDMY (kg ha-1) } \\
\hline Tifleaf 1 & 4,886 & 5,237 & 5,120 & 3,666 & $3,500 \mathrm{~b}$ & $2,922 \mathrm{c}$ & $3,253 \mathrm{c}$ \\
\hline Tifleaf 2 & 4,852 & 5,665 & 5,394 & 4,096 & $4,040 \mathrm{ab}$ & $2,880 \mathrm{c}$ & $3,474 \mathrm{bc}$ \\
\hline Cycle $1 \times$ Tift 383 & 5,692 & 5,873 & 5,813 & 3,683 & $4,479 \mathrm{ab}$ & $3,206 \mathrm{bc}$ & $3,643 a b c$ \\
\hline Cycle $2 \times$ Tift 383 & 4,839 & 5,982 & 5,601 & 4,267 & $3,980 \mathrm{ab}$ & $3,566 \mathrm{ab}$ & $3,845 \mathrm{ab}$ \\
\hline Cycle $3 \times$ Tift 383 & 5,515 & 6,142 & 5,933 & 4,073 & $4,712 \mathrm{a}$ & $3,681 \mathrm{ab}$ & $4,037 \mathrm{a}$ \\
\hline Cycle $4 \times$ Tift 383 & 6,033 & 5,747 & 5,842 & 4,110 & $4,450 \mathrm{ab}$ & $3,834 \mathrm{a}$ & $4,057 \mathrm{a}$ \\
\hline $\operatorname{LSD}(P=0.05)$ & 2,276 & 1,251 & 1,100 & 1,133 & 1,099 & 592 & 477 \\
\hline \multicolumn{8}{|l|}{ Height (dm) } \\
\hline Tifleaf 1 & $14.7 \mathrm{bc}$ & $16.3 \mathrm{~b}$ & $15.7 \mathrm{bc}$ & $14.8 \mathrm{ab}$ & $15.2 \mathrm{~d}$ & $15.4 \mathrm{~b}$ & $15.2 \mathrm{c}$ \\
\hline Tifleaf 2 & $12.9 \mathrm{~d}$ & $16.4 \mathrm{~b}$ & $15.3 \mathrm{c}$ & $14.7 \mathrm{ab}$ & $15.5 \mathrm{~cd}$ & $15.8 \mathrm{ab}$ & $15.4 \mathrm{bc}$ \\
\hline Cycle $1 \times$ Tift 383 & $14.1 \mathrm{c}$ & $16.6 \mathrm{ab}$ & $15.8 \mathrm{bc}$ & $14.6 \mathrm{~b}$ & $15.7 \mathrm{~cd}$ & $15.8 \mathrm{ab}$ & $15.5 \mathrm{bc}$ \\
\hline Cycle $2 \times$ Tift 383 & $14.8 \mathrm{bc}$ & $16.3 \mathrm{~b}$ & $15.8 \mathrm{bc}$ & $14.7 \mathrm{ab}$ & $16.0 \mathrm{bc}$ & $16.3 \mathrm{a}$ & $15.8 \mathrm{ab}$ \\
\hline Cycle $3 \times$ Tift 383 & $16.2 \mathrm{a}$ & $17.8 \mathrm{a}$ & $17.2 \mathrm{a}$ & $14.7 \mathrm{ab}$ & $16.8 \mathrm{a}$ & $16.2 \mathrm{a}$ & $16.0 \mathrm{a}$ \\
\hline Cycle $4 \times$ Tift 383 & $15.7 \mathrm{ab}$ & $17.1 \mathrm{ab}$ & $16.6 \mathrm{ab}$ & $15.4 \mathrm{a}$ & $16.6 \mathrm{ab}$ & $16.2 \mathrm{a}$ & $16.1 \mathrm{a}$ \\
\hline $\operatorname{LSD}(P=0.05)$ & 1.2 & 1.3 & 0.9 & 0.8 & 0.7 & 0.7 & 0.4 \\
\hline \multicolumn{8}{|l|}{ Rust severity (\%) } \\
\hline Tifleaf 1 & $\ldots$ & $\ldots$ & $\ldots$ & $75.3 \mathrm{a}$ & $61.3 \mathrm{a}$ & $67.5 \mathrm{a}$ & $67.9 \mathrm{a}$ \\
\hline Tifleaf 2 & $\ldots$ & $\ldots$ & $\ldots$ & $75.8 \mathrm{a}$ & $63.2 \mathrm{a}$ & $61.8 \mathrm{a}$ & $65.6 \mathrm{a}$ \\
\hline Cycle $1 \times$ Tift 383 & $\ldots$ & $\ldots$ & $\ldots$ & $60.3 \mathrm{ab}$ & $50.8 \mathrm{~b}$ & $42.8 \mathrm{~b}$ & $49.2 \mathrm{~b}$ \\
\hline Cycle $2 \times$ Tift 383 & $\ldots$ & $\ldots$ & $\ldots$ & $52.7 \mathrm{bc}$ & $51.8 \mathrm{~b}$ & $36.1 \mathrm{~b}$ & $44.2 \mathrm{~b}$ \\
\hline Cycle $3 \times$ Tift 383 & $\ldots$ & $\ldots$ & $\ldots$ & $34.6 \mathrm{~d}$ & $28.8 \mathrm{c}$ & $28.2 \mathrm{c}$ & $29.9 \mathrm{c}$ \\
\hline Cycle $4 \times$ Tift 383 & $\ldots$ & $\ldots$ & $\ldots$ & $38.8 \mathrm{~cd}$ & $24.3 \mathrm{c}$ & $26.5 \mathrm{c}$ & $29.0 \mathrm{c}$ \\
\hline $\operatorname{LSD}(P=0.05)$ & $\ldots$ & $\ldots$ & $\ldots$ & 17.0 & 7.5 & 7.4 & 5.7 \\
\hline \multicolumn{8}{|l|}{ AUDPC } \\
\hline Tifleaf 1 & $\ldots$ & $\ldots$ & $\ldots$ & $1,576 \mathrm{a}$ & $1,148 \mathrm{ab}$ & $1,218 \mathrm{a}$ & $1,290 \mathrm{a}$ \\
\hline Tifleaf 2 & $\ldots$ & $\ldots$ & $\ldots$ & $1,760 \mathrm{a}$ & $1,210 \mathrm{a}$ & $1,163 \mathrm{a}$ & $1,324 \mathrm{a}$ \\
\hline Cycle $1 \times$ Tift 383 & $\ldots$ & $\ldots$ & $\ldots$ & $1,243 \mathrm{~b}$ & $1,010 \mathrm{c}$ & $779 \mathrm{~b}$ & $953 \mathrm{~b}$ \\
\hline Cycle $2 \times$ Tift 383 & $\ldots$ & $\ldots$ & $\ldots$ & $1,124 \mathrm{bc}$ & $1,046 \mathrm{bc}$ & $667 \mathrm{~b}$ & $876 b$ \\
\hline Cycle $3 \times$ Tift 383 & $\ldots$ & $\ldots$ & $\ldots$ & $789 \mathrm{~d}$ & $654 \mathrm{~d}$ & $503 \mathrm{c}$ & $612 \mathrm{c}$ \\
\hline Cycle $4 \times$ Tift 383 & $\ldots$ & $\ldots$ & $\ldots$ & $863 \mathrm{~cd}$ & $571 \mathrm{~d}$ & $477 \mathrm{c}$ & $597 \mathrm{c}$ \\
\hline $\operatorname{LSD}(P=0.05)$ & $\ldots$ & $\ldots$ & $\ldots$ & 316 & 118 & 117 & 102 \\
\hline
\end{tabular}

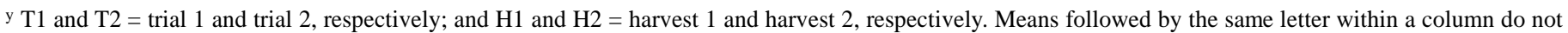
differ significantly $(P=0.05)$.

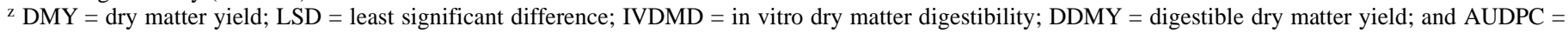
area under the disease progress curve. 
races within mixtures suggests that environmental interactions, genetic background of the pathogen race, host composition, and interaction among races are likely to be important factors in determining race predominance in host mixtures (3).

Intermating during cultivar increase will result in possible fluctuations in gene frequencies; therefore, the seasonal variation of resistance gene and gene combination frequencies within the host population should buffer against rapid changes in virulence gene frequencies in the pathogen population. As virulence gene frequencies change, the resulting change in disease pressure by prevailing and predominant pathogen races should select for more effective resistance gene and gene combinations during foundation seed production. Theoretical models of the evolution of complex races (6) have generally focused on genetically static host populations. In contrast to the traditional approaches of attempting to maintain resistance of a genetically static host population, this breeding method has the potential of confronting a variable and dynamic pathogen population with a variable and dynamic host population. These advantages encourage application of the dynamic multiline population concept in other pathosystems.

\section{ACKNOWLEDGMENTS}

This study was a cooperative investigation of the USDA-ARS and the University of Georgia Agricultural Experiment Station. Partial support of this research was provided by the U.S. Department of Energy grant DEFG05-93ER20099. We thank T. Perla and J. Dillard for their technical assistance.

\section{LITERATURE CITED}

1. Bidinger, F. R., Weltzien, E., Mahalakshmi, R. V., Singh, S. D., and Rao, K. P. 1994. Evaluation of landrace topcross hybrids of pearl millet for arid zone environments. Euphytica 76:215-226.

2. Chin, K. M., and Wolfe, M. S. 1984. The spread of Erysiphe graminis f. sp. hordei in mixtures of barley varieties. Plant Pathol. 33:89-100.

3. Dileone, J. A., and Mundt, C. C. 1994. Effect of wheat cultivar mixtures on populations of Puccinia striiformis races. Plant Pathol. 43:917-930.

4. Ibrahim, K. M., and Barrett, J. A. 1991. Evolution of mildew resistance in a hybrid bulk population of barley. Heredity 67:247-256.

5. Kareiva, P. 1999. Coevolutionary arms races: Is victory possible? Proc. Natl. Acad. Sci. 96:8-10.

6. Lannou, C., and Mundt, C. C. 1997. Evolution of a pathogen population in host mixtures: Rate of emergence of complex races. Theor. Appl. Genet. 94:991-999.

7. Mahalakshmi, V., Bidinger, F. R., Rao, K. P., and Raju, D. S. 1992. Performance and stability of pearl millet topcross hybrids and their variety pollinators. Crop Sci. 32:928-932.

8. Marshall, D. R., and Weir, B. S. 1985. Multiline varieties and disease control. vol. 5. The "dirty crop" approach with complex mixtures of genotypes based on overlapping gene sets. Theor. Appl. Genet. 69:463474.

9. McDonald, B. A., Allard, R. W., and Webster, R. K. 1988. Responses of two-, three-, and four-component barley mixtures to a variable pathogen population. Crop Sci. 28:447-452.

10. Mundt, C. C., and Leonard, K. J. 1985. Effect of host genotype unit area on epidemic development of crown rust following focal and general inoculations of mixtures of immune and susceptible oat plants. Phytopathology 75:1141-1145.

11. Pielou, E. C. 1975. Ecological Diversity. John Wiley \& Sons, New York.

12. Tapsoba, H., and Wilson, J. P. 1996. Pathogenic variation in Puccinia substriata var. indica in the southeastern United States and screening for resistance in pearl millet germ plasm. Plant Dis. 80:395-397.

13. Tapsoba, H., and Wilson, J. P. 1999. Increasing genetic complexity in host mixtures through intermating to manage rust of pearl millet. Phytopathology 89:450-455.

14. Tapsoba, H., Wilson, J. P., and Hanna, W. W. 1997. Improvement of resistance to rust through recurrent selection in pearl millet. Crop Sci. 37:365-369.

15. Thakur, R. P. 1990. Basic research on management of pearl millet diseases. Pages 343-358 in: Basic Research for Crop Disease Management. P. Vidhyasekaran, ed. Daya, New Delhi, India.

16. Trenbath, B. R. 1984. Gene introduction strategies for the control of crop diseases. Pages 142-168 in: Pest and Pathogen Control: Strategic, Tactical, and Policy Models. G. R. Conway, ed. John Wiley \& Sons, Chichester, U.K.

17. Vogel, K. P., Pedersen, J. F., Nasterson, S. D., and Toy, J. J. 1999. Evaluation of a filter bag system for NDF, ADF, and IVDMD forage analysis. Crop Sci. 39:276-279.

18. Wilson, J. P. 1993. Identification of virulence in Puccinia substriata var. indica to $R r_{1}$ in pearl millet. Plant Dis. 77:100.

19. Wilson, J. P. 1994. Field and greenhouse evaluations of pearl millet for partial rust resistance to Puccinia substriata var. indica. Plant Dis. 78:1202-1205.

20. Wilson, J. P., and Gates, R. N. 1999. Disease resistance and biomass stability of forage pearl millet hybrids with partial rust resistance. Plant Dis. 83:733-738.

21. Wilson, J. P., Gates, R. N., and Hanna, W. W. 1991. Effect of rust on yield and digestibility of pearl millet forage. Phytopathology 81:233236.

22. Wilson, J. P., Hanna, W. W., and Bondari, K. 1993. Directed use of germplasm resources in breeding rust resistant pearl millet. Trends Agric. Sci. (Plant Pathol.) 1:67-74.

23. Witcombe, J. R., and Hash, C. T. 2000. Resistance gene deployment strategies in cereal hybrids using marker-assisted selection: Gene pyramiding, three-way hybrids, and synthetic parent populations. Euphytica 112:175-186.

24. Xu, X.-M., and Ridout, M. S. 2000. Stochastic simulation of the spread of race-specific and race-nonspecific aerial fungal pathogens in cultivar mixtures. Plant Pathol. 49:207-218.

25. Yadav, O. P., Weltzien-Rattunde, E., Bidinger, F. R., and Mahalakshmi, V. 2000. Heterosis in landrace-based topcross hybrids of pearl millet across arid environments. Euphytica 112:285-295. 